\title{
CHROMATE-FREE COATINGS FOR CORROSION PROTECTION OF THE SURFACE OF THE ELECTRODEPOSITED Zn-Ni ALLOY
}

\author{
${ }^{1}$ ABRASHOV Aleksey, ${ }^{1}$ ADUDIN Igor', ' GRIGORYAN Nelya, ${ }^{1}$ ORLOVA Kseniya, ${ }^{2}$ GRAFOV Oleg, \\ ${ }^{1}$ VAGRAMYAN Tigran, ${ }^{1}$ SHEPELEVA Aleksandra \\ ${ }^{1}$ MUCTR - D.Mendeleev University of Chemical Technology of Russia, Moscow, Russia, \\ abr-aleksey@yandex.ru \\ 2IPCE RAS - A.N. Frumkin Institute of Physical Chemistry and Electrochemistry, Russian Academy of \\ Sciences, Moscow, Russian Federation, Russia,grafov.oleg88@gmail.com
}

https://doi.org/10.37904/metal.2021.4183

\begin{abstract}
In this work, the processes of applying protective conversion coatings based on rare-earth metal compounds for passivation of the surface of a $\mathrm{Zn}-\mathrm{Ni}$ alloy were investigated. The mechanism of formation, composition and corrosion characteristics of passivating films were investigated. It is shown that the investigated chromate-free coatings are comparable to rainbow chromate layers in corrosion resistance and protective ability. It was found that these coatings withstand thermal shock without deterioration of functional characteristics. It has been revealed that cerium-, lanthanum-containing coatings, like chromate coatings, have the ability to self-heal.
\end{abstract}

Keywords: Corrosion protection, conversion coatings, cerium-containing coatings, lanthanum-containing coatings, surface treatment, chromate-free passivation.

\section{INTRODUCTION}

The protective and decorative zinc-nickel coatings are widely used in automobile industry, in the factories of BMW, Audi, Fiat, Renault etc., as they can easily tolerate high operation temperatures $\left(100-160^{\circ} \mathrm{C}\right)$, realized in the engine compartment of cars in warm climates [1-3]. Currently about $60 \%$ of $\mathrm{Zn}-\mathrm{Ni}$ alloy coatings are used in the automobile industry, $10 \%$ - in power lines, $15 \%$ - in military equipment, $15 \%$ - for covering various fasteners and metal products in other industries.

The demand for zinc-nickel alloy coatings has increased since the adoption of the European directive in 2011 completely prohibiting the presence of toxic cadmium in the elements and structures of electrical and electronic equipment [4]. Since 2016, the use of cadmium in electrical and radio-electronic products has also been banned on the territory of the Russian Federation [5]. However, the corrosion resistance of zinc-nickel alloy coatings is lower than that of cadmium coatings; therefore, in order to increase the corrosion resistance of $\mathrm{Zn}$ $\mathrm{Ni}$ alloys, passivation processes are used.

To improve the corrosion resistance of galvanic zinc-nickel alloy protective coatings, chromate treatment processes are applied. The resulting conversion chromate films inhibit corrosion processes on the surfaces of these metals and, in addition, have the ability to self-heal at mechanical damage of the film. It is known that chromate solutions are highly toxic due to the hexavalent chromium ions. The problem of replacing the chromating processes has become critical after the adoption of the European Directive 2000/53/EC in 2000 restricting the presence of $\mathrm{Cr}(\mathrm{VI})$ compounds in conversion coatings [6], and in 2002 the amendments to the directive, which completely prohibits from July 2007 the presence of $\mathrm{Cr}(\mathrm{VI})$ in conversion coatings applied in the production of automobiles [7]. Similar directives have come into operation in China since March 1, 2007, and in South Korea since July 1, 2007. In addition, RoHS [8] and WEEE [9 prohibit the 
presence of $\mathrm{Cr}(\mathrm{VI})$ in metallic coatings of electrical and electronic equipment; the use of $\mathrm{Cr}(\mathrm{VI})$ limits the $\mathrm{REACH}$ regulation [10].

In recent years, publications on the possibility of using conversion cerium- and/or lanthanum-containing coatings as an alternative to chromate layers on zinc and its alloys have appeared. Salts of rare-earth metals, in particular cerium and lanthanum salts are environmentally friendly and effective corrosion inhibitors of metals such as aluminum and zinc and their alloys [11-14]. In view of the foregoing, cerium- or lanthanum-containing conversion coatings can become a possible substitute for adhesive conversion chromate coatings.

\section{EXPERIMENTAL MATERIALS}

Samples of cold-rolled steel of the 08ps grade, coated with a galvanic zinc-nickel alloy, widely used in the automotive industry, were used as samples. The deposition of a galvanic zinc-nickel alloy was carried out in an electrolyte of the following composition: $\mathrm{ZnO} 4,5-9 \mathrm{~g} / \mathrm{l} ; \mathrm{NaOH} 50-112,5 \mathrm{~g} / \mathrm{l} ; \mathrm{NiSO}_{4} \cdot 7 \mathrm{H}_{2} \mathrm{O}$ 1,75 - 3,5 g/l; LAO 12,5 - $50 \mathrm{~g} / \mathrm{l}\left(\mathrm{i}_{\mathrm{c}} \mathrm{A} / \mathrm{dm}^{2}-2,0 ; \mathrm{t} 22^{\circ} \mathrm{C} ; \mathrm{pH} 13,0-14,0\right)$.

An express method using a solution containing $\mathrm{Pb}\left(\mathrm{CH}_{3} \mathrm{COO}\right)_{2} 50 \mathrm{~g} / \mathrm{l}$ was used to evaluate the protective ability of conversion cerium-containing coatings. According to this method, the protective ability of the coating was estimated in seconds, like the time before the color change of the control section from the transparent to black under a drop of a solution on a zinc base.

The thickness of the coatings was determined by ellipsometric method using the spectroscopic ellipsometer SENreseach 4.0 from SENTECH.

The composition of the surface layers was studied using X-ray photoelectron spectroscopy (Omicron, Taunusstein, Germany) (XPS). The panoramic spectra were also recorded after argon-ion etching of the coating in different depths. Thus, the composition of the coating at different distances from the substrate was determined. The pressure of the inert gas in the working chamber was maintained at this level, so that the ion energy and the ion current rate, and consequently, the etching rate, were constant. When analyzing the obtained spectra, it was considered that the analyzing beam penetrates the material to the depth of $5 \mathrm{~nm}$, i.e., the resulting spectra correspond to a layer of material $5 \mathrm{~nm}$ thick.

To determine the self-healing ability of the applied coatings, transverse incisions were made on the surface. The area was photographed with the LEXT-OSL 4100 confocal laser microscope. The samples were then placed in a $0.03 \mathrm{M} \mathrm{NaCl}$ solution. After a predetermined time (48 hours), the samples were removed from the chamber, dried in air, and then again photographed the same section of the sample surface.

Corrosion tests were carried out in a salt fog chamber Ascott S450iP in accordance with the international standard ASTM B117.

Current-voltage and impedance studies were carried out using an IPC potentiostat with an FRA attachment and a three-electrode glass cell thermostated at $25^{\circ} \mathrm{C}$ in $3 \% \mathrm{NaCl}$. The counter electrode was a titanium plate, the surface area of which significantly exceeded the overall area of the working electrode. The potentials were measured relative to a saturated silver -chloride electrode and then recalculated to the scale of a standard hydrogen electrode. The potential sweep rate when obtaining voltammograms was $50 \mathrm{mV} / \mathrm{s}$. The impedance was measured in a potentiostatic mode at a stationary potential in the frequency range $0.1 \mathrm{~Hz}-20 \mathrm{kHz}$ at a potential oscillation amplitude of $10 \mathrm{mV}$.

To analyze the equivalent circuits and calculate the denominations of their elements, the DCS program (Dummy Cell Solver), created by V.E. Kasatkin (IPCE RAS), was used. This program allows you to calculate the theoretical frequency dependence of the impedance of the selected circuit and compare it with the experimentally obtained dependence. The optimization of the nominal values of the elements of the selected equivalent circuit is performed according to the criterion of minimizing the relative error between the 
experimental and simulated values of the impedance vectors for each measurement in the investigated range.

\section{EXPERIMENTAL}

Technological processes of deposition of cerium- and lanthanum-containing coatings on galvanized steel, developed earlier at the Department of Innovative Materials and Corrosion Protection (Mendeleev University of Chemical Technology of Russia, Russian Federation), were selected as objects of research. The compositions of solutions and process parameters are given in (Table 1). [15,16].

Table 1 Compositions of solutions and parameters

\begin{tabular}{|l|c|c|c|}
\hline \multicolumn{1}{|c|}{ Compound } & №1 & №2 & №3 \\
\hline $\mathrm{Ce}\left(\mathrm{NO}_{3}\right)_{3} \times 6 \mathrm{H}_{2} \mathrm{O}, \mathrm{g} / \mathrm{l}$ & 9,3 & - & 6,2 \\
\hline $\mathrm{La}\left(\mathrm{NO}_{3}\right) \times 6 \mathrm{H}_{2} \mathrm{O}, \mathrm{g} / \mathrm{l}$ & - & 12 & 3,12 \\
\hline $\mathrm{H}_{2} \mathrm{O}_{2}(37 \%)$ & 10 & 10 & 10 \\
\hline $\mathrm{H}_{3} \mathrm{BO}_{3}, \mathrm{~g} / \mathrm{l}$ & 1,3 & 1,3 & 1,3 \\
\hline \multicolumn{3}{|c|}{ Process parameters } \\
\hline $\mathrm{pH}$ & $2,5-3$ & $2,5-3$ & $2,5-3$ \\
\hline Solution temperature, ${ }^{\circ} \mathrm{C}$ & $40-50$ & $40-50$ & $40-50$ \\
\hline Duration of the process, $\mathrm{s}$ & $45-60$ & $45-60$ & $45-60$ \\
\hline Drying temperature, ${ }^{\circ} \mathrm{C}$ & $70-80$ & $70-80$ & $70-80$ \\
\hline Drying time, min & $10-15$ & $10-15$ & $10-15$ \\
\hline
\end{tabular}

Lanthanum and cerium ions were introduced into the solution in the form of their nitric acid salt $\left[\mathrm{La}\left(\mathrm{NO}_{3}\right)_{3} \cdot 6 \mathrm{H}_{2} \mathrm{O}\right],\left[\mathrm{Ce}\left(\mathrm{NO}_{3}\right)_{3} \cdot 6 \mathrm{H}_{2} \mathrm{O}\right]$ and hydrogen peroxide $\left(\mathrm{H}_{2} \mathrm{O}_{2}\right)$ was used as an oxidizing agent.

\subsection{Investigation of the chemical composition of the forming coatings}

The chemical composition of the forming cerium- and lanthanum-containing coatings has been investigated. The survey XPS spectra of the coating formed in the working solution №1 indicate the presence of oxygen, cerium, zinc and nickel in the coating. From the individual spectra of cerium (Figure 1 a), zinc (Figure1b), nickel (Figure 1c), and oxygen (Figure 1d), it can be seen that cerium is present in the coating in the form of $\mathrm{CeO}_{2}$ oxide, zinc in the form of $\mathrm{ZnO}$ and $\mathrm{Zn}(\mathrm{OH})_{2}$, nickel in the form of $\mathrm{Ni}(\mathrm{OH})_{2}$. It was found that nickel is included only in the cerium-containing coating formed from solution №1. The lanthanum-containing coating consists of $\mathrm{La}_{2} \mathrm{O}_{3}, \mathrm{ZnO}$ and $\mathrm{Zn}(\mathrm{OH})_{2}$. Ce-, La-containing coating formed from working solution №3 consists of $\mathrm{CeO}_{2}, \mathrm{La}_{2} \mathrm{O}_{3}, \mathrm{ZnO}$ and $\mathrm{Zn}(\mathrm{OH})_{2}$.

\subsection{Tests of the coatings}

In order to identify the possibility of operating coatings under high-temperature conditions (thermal shock), the samples were heated for 1 hour at a temperature of $160^{\circ} \mathrm{C}$. It was found that the protective ability of ceriumcontaining, lanthanum-containing and cerium-, lanthanum-containing coatings after thermal shock did not change, while the protective ability of chromate coatings, as expected, decreased to 20 seconds.

It is known that in the presence of small damage, the chromate film is capable of secondary passivation, since the moisture present on the surface leaches chromic acid ions, which fall on the bare places and again passivate zinc and its alloys. The ability of cerium- and lanthanum-containing coatings to self-generation has been determined. Using confocal microscope, it was revealed that the scratch after 48 hours is almost 
completely overgrown by the formed coating, thus it was shown that cerium-containing and Ce, La-containing coatings have the ability to self-heal (Figure 2).
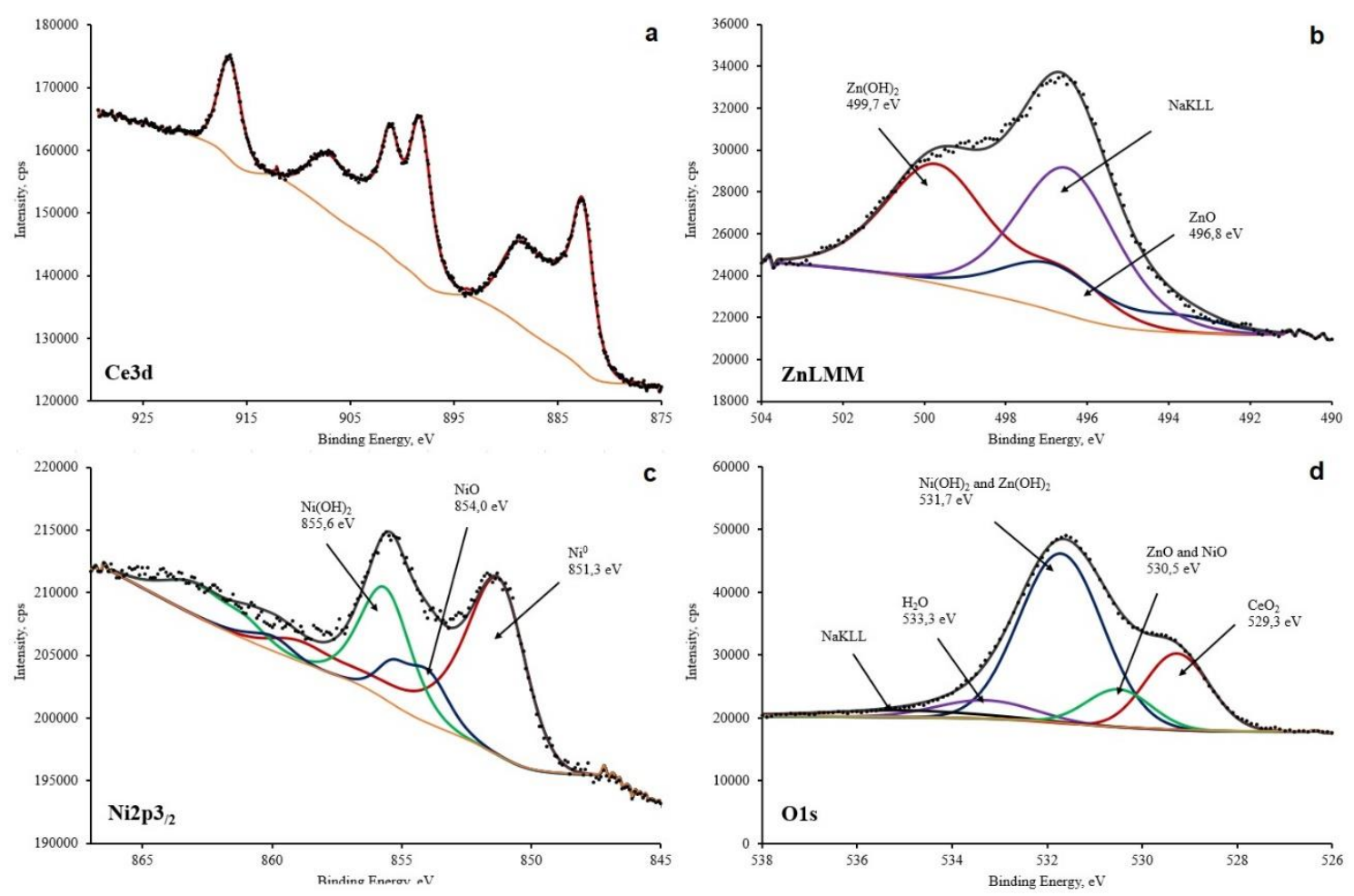

Figure 1 Individual XPS spectra of cerium (a) zinc (b), nickel (c) and oxygen (d) in the cerium-containing coating
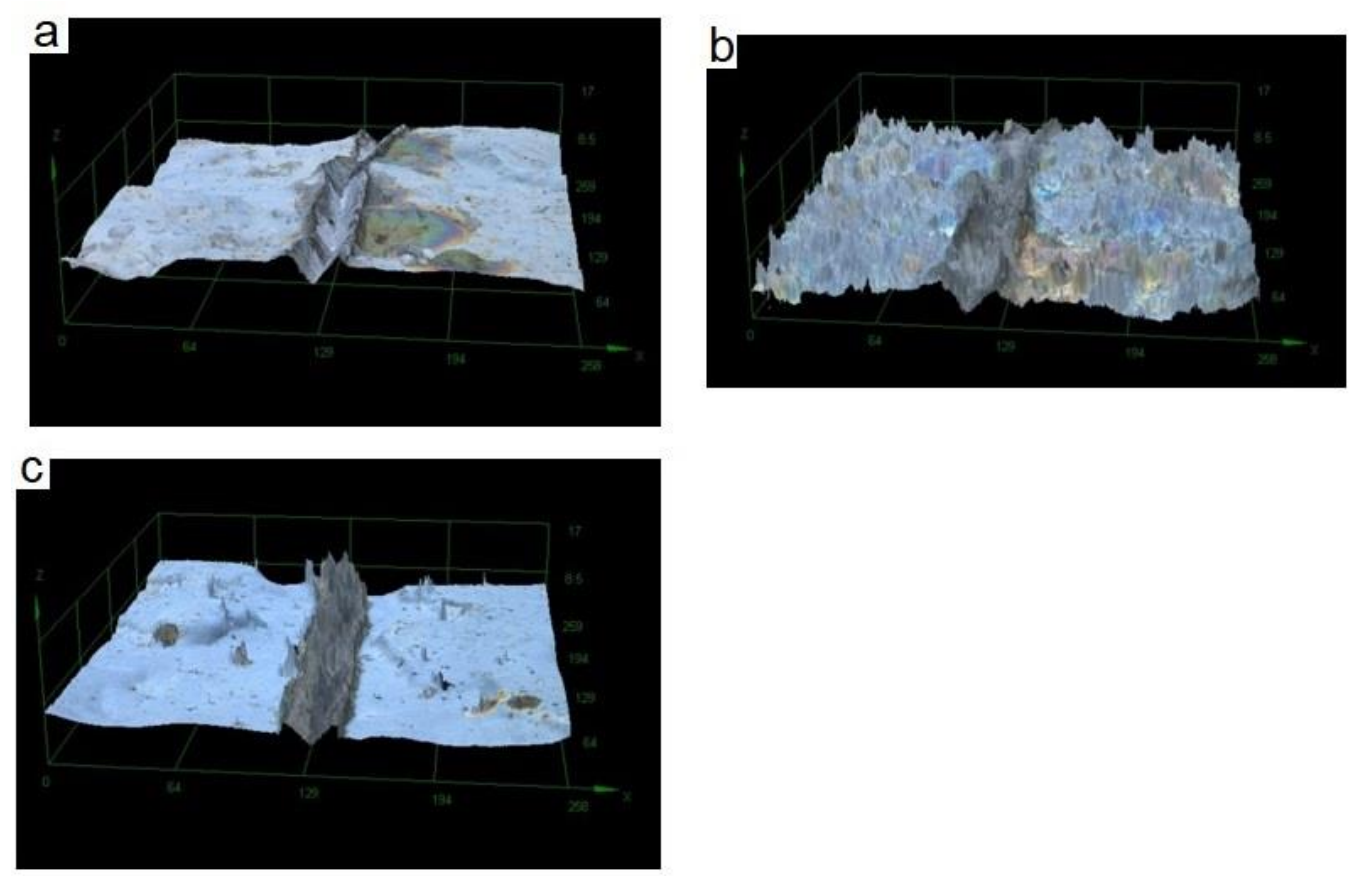

Figure 2 Image of a scratch on the coating before and after testing in $0.03 \mathrm{M} \mathrm{NaCl}$ solution:

a) before testing; b) cerium-containing coating after 48 hours of testing; c) cerium-, lanthanum-containing coating after 48 hours of testing 
It is known that the ability of chromate films to self-regenerate - to "self-heal" is based on the following reactions:

$$
\begin{aligned}
& \mathrm{Cr}(\mathrm{OH}) \mathrm{CrO}_{4}+2 \mathrm{H}_{2} \mathrm{O}=\mathrm{Cr}(\mathrm{OH})_{3}+\mathrm{H}_{2} \mathrm{CrO}_{4} \\
& (\mathrm{ZnOH})_{2} \mathrm{CrO}_{4}+2 \mathrm{H}_{2} \mathrm{O}=2 \mathrm{Zn}(\mathrm{OH})_{2}+\mathrm{H}_{2} \mathrm{CrO}_{4}
\end{aligned}
$$

where the moisture present on the surface leaches chromic acid ions, which fall on the bare places and again passivate zinc.

It can be assumed that in the case of cerium- and $\mathrm{Ce}$, La-containing coatings in the presence of moisture on the bare area, the following reactions will occur:

$\mathrm{Zn} \rightarrow \mathrm{Zn}^{2+}+2 \mathrm{e}^{-}$

$\mathrm{O}_{2}+2 \mathrm{H}_{2} \mathrm{O}+4 \mathrm{e}^{-} \rightarrow 4 \mathrm{OH}^{-}$

$\mathrm{Zn}^{2+}+2 \mathrm{OH}^{-} \rightarrow \mathrm{Zn}(\mathrm{OH})_{2}$

$4 \mathrm{Ce}(\mathrm{OH})_{2}{ }^{2+}+2 \mathrm{OH}-\rightarrow 4 \mathrm{Ce}^{3+}+5 / 2 \mathrm{O}_{2}+5 \mathrm{H}_{2} \mathrm{O}$

It should be noted that self-healing properties have not been found on lanthanum-containing coatings. Apparently, this is due to the fact that lanthanum, unlike cerium, has only one valency +3 and it has no opportunity to be reduced to a lower valence state.

Corrosion tests (ASTM B117) in a salt spray chamber were carried out. It has been established that the time before the appearance of the first spot of white corrosion on cerium- and lanthanum-containing coatings is 180 hours, which is higher than the protective ability of rainbow chromate coatings (170 hours).

In this work, impedance spectroscopy was also used to compare the protective characteristics of conversion coatings.

It is known that Nyquist diagrams (hodographs) show charge transfer resistance from solution to metal and vice versa, so the larger the hodograph loop, the more difficult this process is, and, therefore, the hodographs can be used to assess the barrier characteristics of the coatings (Figure 3 ).

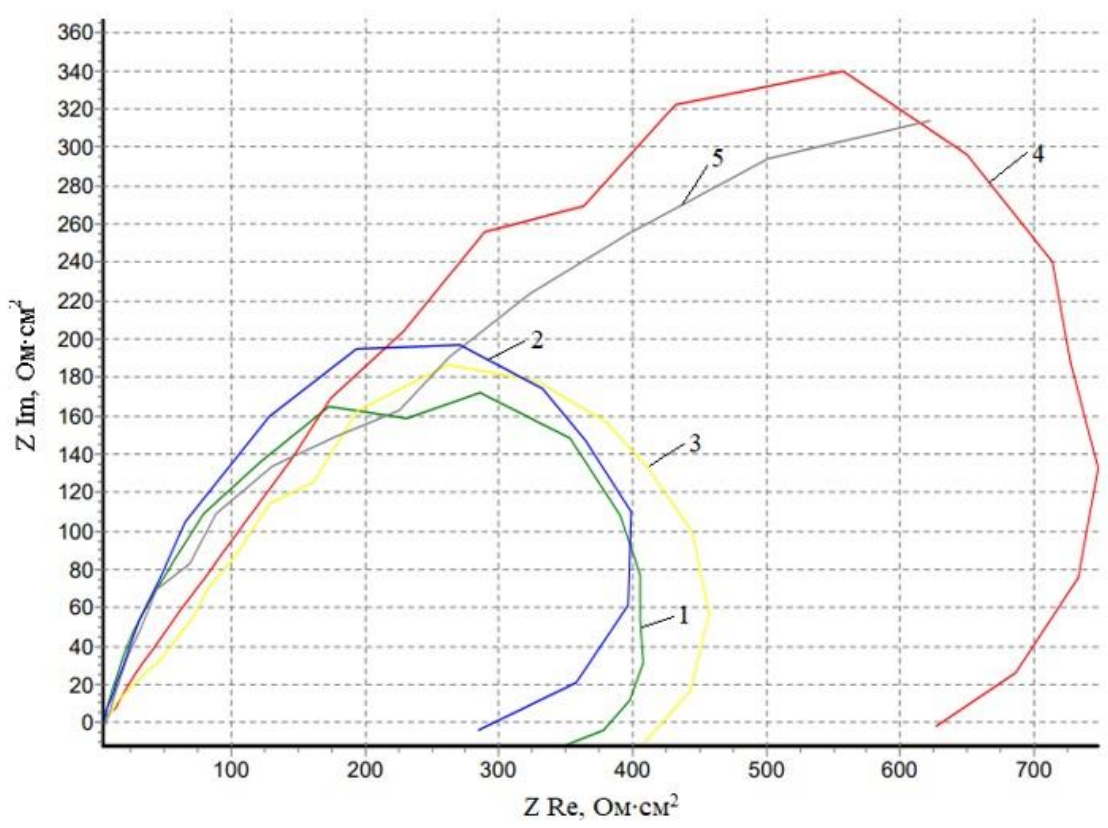

Figure 3 Nyquist diagrams for Zn-Ni alloys with protective coatings:

$$
1 \text { - Zn-Ni; } 2 \text { - La; } 3 \text { - Ce; } 4 \text { - Ce-La; } 5 \text { - Cr (VI) }
$$


The given hodographs indicate that the greatest difficulties in charge transfer occur in the case of Ce, Lacontaining coating. The hodograph radii of samples with $\mathrm{Ce}$, La- and chromate coatings are comparable.

It should be noted that the results of impedance spectroscopy are consistent with the above results of corrosion tests.

\section{CONCLUSION}

As a result of this study, it was found that the developed cerium-, lanthanum-containing passivating coatings on the zinc-nickel alloy are comparable in corrosion resistance and protective ability to chromate coatings and can be an alternative to the latter.

\section{ACKNOWLEDGEMENTS}

\section{The work was supported by the Mendeleev University of Chemical Technology of Russia. Project Number X-2020-028}

\section{REFERENCES}

[1] WEN, X., YANG, Z., XIAO, X., YANG, H., XIE, X. and HUANG, J., The Impact of Hydrocalumites Additives on the Electrochemical Performance of Zinc-Nickel Secondary Cells. Electrochim. Acta. 2016, vol. 187, pp. 65-72.

[2] KWON, M., JO, D-H., CHO, S.H., KIM, H.T., PARK, J-T., PARK J.M. Characterization of the influence of Ni content on the corrosion resistance of electrodeposited Zn-Ni alloy coatings, Surf. Coat. Technol. 2016, vol. 288, pp. 163170.

[3] QIAO, X., LI, H., ZHAO, W. and LI, D., Effects of deposition temperature on electrodeposition of zinc-nickel alloy coatings, Electrochim. Acta. 2013, vol. 89, pp. 771-777.

[4] Directive 2011/65/EU (RoHS II) of European Parliament and Council of 8 June 2011 on the restriction of the use of certain hazardous substances in electrical and electronic equipment.

[5] Technical Regulations of the Eurasian Economic Community "On the Restriction of the Use of Hazardous Substances of Electrical and Electronic Products" (TR EAEU 037/2016) (approved by the Council of the Eurasian Economic Commission on October 18, 2016, no. 113).

[6] Directive 2000/53/EC of the Parliament and the Council of Europe on September 18, 2000 "End-of-live-vehicles", Official Journal of the European Communities L269. pp. 34-43.

[7] Replacement hexavalent chromium in automotive industry for ELV Directive. // Harris A. Bhatt, technical paper, Sur/Fin. 6/2002.

[8] Directive 2011/65 / EC (RoHS II) of the European Parliament and of the Council of 8 June 2011 on the restriction of the use of certain hazardous substances in electrical and electronic equipment.

[9] Directive 2002/96 / EC of the European Parliament and of the Council of 27 January 2003 on waste electrical and electronic equipment.

[10] Regulation (EC) No 1907/2006 of the European Parliament and of the Council of 18 December 2006 concerning the registration, assessment, authorization and limitation of chemicals $(\mathrm{REACH})$, the establishment of the European Chemicals Agency.

[11] ZHELUDKOVA, E.A., ABRASHOV, A.A., GRIGORYAN, N.S., VAGRAMYAN, T.A. Passivation of Zinc Coatings in Cerium-containing Solutions. Adnvances in Chemistry and Chemical Technology. 2015, vol. 29, no 2 (161), pp. 83-85.

[12] LIU, GUANGMINGA, YU, FEIB, YANG, LIUA, et. al. Cerium-tannic acid passivation treatment on galvanized steel. Rare metals. 2009, vol. 28, no. 3, p. 284.

[13] GOBARA, M., BARAKA, A., AKID, R., ZORAINY, M., Corrosion protection mechanism of Ce ${ }^{4+/ o r g a n i c ~ i n h i b i t o r ~ f o r ~}$ AA2024 in 3.5\% NaCl. RSC Advances. 2020, vol. 10, pp. 2227-2240. 
[14] RAHMAN, M.M., ZAHIR, MD.H., HAQ, MD.B., SHEHRI, D.A. AL, KUMAR, A.M. Corrosion Inhibition Properties of Waterborne Polyurethane/Cerium Nitrate Coatings on Mild Steel. Coatings. 2018, vol. 8, p. 34.

[15] ABRASHOV, A.A., GRIGORYAN, N.S., KONDRAT'EVA, N.D., ZHELUDKOVA, E.A., MIROSHNIKOV, V.S., MAZUROVA, D.V. Beskhromatnaya passivaciya ocinkovannoj stali v rastvore na osnove nitrata lantana (Chromate-free passivation of galvanized steel in a solution based on lanthanum nitrate). Himicheskaya bezopasnost'. 2020, vol.4, no.2, pp. 198-211.

[16] ZHELUDKOVA, E.A., ABRASHOV, A.A., GRIGORYAN, N.S., ASNIS, N.A., VAGRAMYAN, T.A. CeriumContaining Solution for Chromate-Free Passivation of Zinc Coatings. Protection of Metals and Physical Chemistry of Surfaces, 2019, vol. 55, no. 7, pp. 1329-1334. 